\title{
Topographic Research upon the Subsidence in the East of the Mining Basin of Petroşani
}

\author{
Maricel PALAMARIU ${ }^{1 *}$, Mircea BELDEA ${ }^{2}$ and Ioan VOINA ${ }^{3}$ \\ ${ }^{1}$ Department of Topography and Cadastre, University “1 Decembrie 1918” Alba-Iulia, Romania \\ ${ }^{2}$ Department of Mining Engineering, Topography and Constructions, University of Petroşani,Romania \\ ${ }^{3}$ Department of Topography and Cadastre, Technical University of Construction, Romania. \\ *)Corresponding author, e-mail: mpalamariu@gmail.com
}

BulletinUASVM Horticulture 73(1) / 2016

Print ISSN 1843-5254, Electronic ISSN 1843-5394

DOI:10.15835/buasvmcn-hort:11579

\begin{abstract}
The research upon the influence of the underground mining upon the surface represent a primordial preoccupation in order to highlight the moving phenomenon and to take the required measures for the protection of the surface and its existing objectives. Thus, the necessity of monitoring the studied phenomenon and the need for prognosis in taking decisions for a durable development leads to the apparition and the creation of topographic techniques and concepts for obtaining information, using the installation in the studied area of marks to observe the deformation and the movement of the surface. The object of this paper is the monitoring process in the East area of the coalfield in Valea Jiului. The documentation for the research in the present paper was made in Compania Nationala a Huilei S.A. of Petrosani, Romania and the measuring was performed in the eastern area of the coalfield. After processing and analysing data and information, a comparison was made between the existing data inside the host company and the data from the field, gathered with the method of radiation with the help of dedicated modern technology, leading to concrete results. The results presented in our study in tables, diagrams, reports and comparisons permit a prognosis of the influence the subsidence has upon the anthropic environment, helping to take correct decisions, necessary to a durable development in the affected area from the eastern part of Valea Jiului coalfield. The paper highlights the fact that subsidence continues to be of large interest due to its involvement in the problems of environmental protection and the protection of the constructions at the surface. The research leads to the conclusion that, following observations in the areas affected by underground exploitation, prognosis on short, medium and long time are possible for the studied phenomenon. These prognoses have a special importance because they can be used for future studies for a durable development of the areas affected by the underground mining.
\end{abstract}

Keywords: prognosis, research, subsidence, topography

\section{INTRODUCTION}

The research upon the influence of the underground mining upon the surface represents a primordial necessity in order to understand the dislocation of the crust and the protection requirements for the surface and the objectives located at the surface. Most of the time, mining has consequences upon the surface, materialised in dozens meters sinking. The dislocation of the surface generated by mining is of capital importance especially for the complete exploration of the coal strata, of the thick strata or of a succession of strata. The areas with civil or industrial objectives may present cracks in the buildings, leading to their destruction, cavities where rain water gathers, cracks in the infrastructure of the communication, gas and water networks etc. The sinking is often produced instantly and the breaking of equilibrium between strata may lead to catastrophes (Marian, 2012).

For the determinations necessary for the strain and displacement of the surface and of the constructions at the surface during undermining, the topographic measurements are frequently used. The displacement parameters (sinking, horizontal displacement) and the deformation 
parameters (inclination, curvature, and horizontal deformations) are determined based on these observations. The problem of the massive rocks displacement and of the covering surface displacement under the influence of the coal mining has an important place in the scientific research of the specialists in the mining topography and other domains (Ortelecan, 1997).

The necessity of studying the subsidence phenomenon appeared together with the development of the mining industry and, especially, with the passing from the surface to the underground mining. The first study upon the surface displacement as a result of underground mining for stratiform deposits was performed in Europe, at the beginning of the $19^{\text {th }}$ century, when the coal exploitation in Liege (Belgium) caused a mass destruction of the construction situated above the mining field. 1839 was the year of the first legal complaints in order to obtain compensations for the damages. The first mathematical formula for the calculation of sinking was created by the French engineer G. Doumont in 1871, as follows:

$v z=M \times \cos \alpha$

where: $M$ represents the thickness of the exploited

strata and $\alpha$ represents the inclination angle of the strata;

The formula shows that, in the case of horizontal strata, when the angle $\alpha=0$, the sinking of the land is equal to the thickness of the exploited strata. The information gathered in the last years for the study of subsidence phenomenon was successfully applied to other domains, e.g. the form of the river beds may be predicted through special calculations.

Comparison between a constructions in the influence area of exploitation for strata 3, block

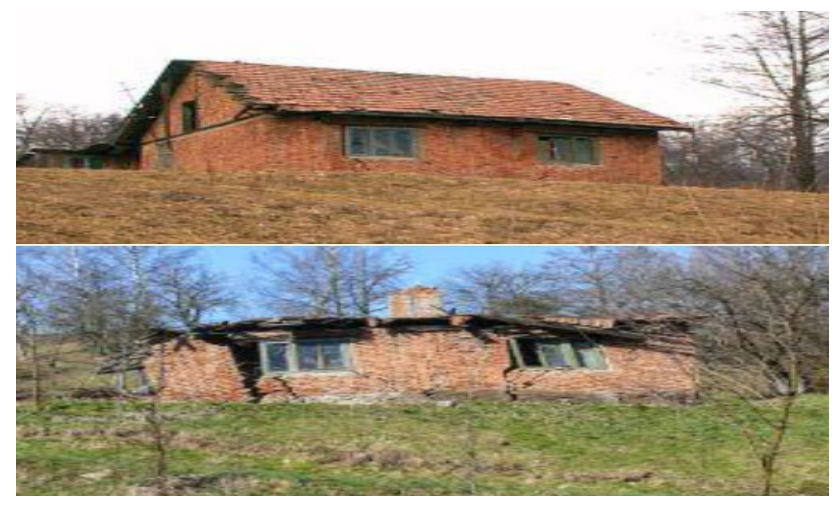

Fig. 1. Negative effects of subsidence.
III in February 2008 and April 2015, in Petrila (Beldea, 2015)

The necessity of monitoring the subsidence and the prognoses of the future influence in order to take the required decisions for a durable development of the affected areas led to the creation of topographic techniques and concepts specific for the obtaining of information through the repeated determination of the marks positions in the observance of strain and displacement of the surface (Neamţu et al., 1988).

The present study is based on a thorough research of the subsidence form a topographic and geodesic perspective, where the data base was obtained as a result of topographic measurements performed by specialised personnel from Complexul Energetic Hunedoara, the former Compania Naţională a Huilei S.A. of Petroșani, România (September 2009), also as a result of topographic measurements performed by us in April 2015.

The objective of the research is to present the recent monitoring procedures in the eastern area of Petroşani mining basin, more exactly in the urban area of Petrila, Lunea residential area, Deforului street, in order to find efficient rehabilitation or development solutions for the development of the area, according to the real situation in the field and the effects of the subsidence.

The displacement and the deformation of the field and of the constructions presented a slow evolution, but one continuous in time, so, they are nowadays freely observable, even without any measurement techniques. The cracks in the land and constructions, the inclination of the walls and the fallen walls may be observed in Deforului Street, at the end of the road linking the street to the rest of the urban area in Lonea residential area, in Petrila. The lake at the end of this road is a result of subsidence, being bordered in the direction of the town by the northern side of the sinking bed and in the southern side by the talus of the former waste dump of Defor pit (Beldea, 2015).

Our research aims to determine the characteristic parameters of the sinking bed as a consequence of the existing mining exploitation. Knowing the parameters is necessary to take the required protection measures for the surface and the objectives at the surface. The sinking bed represents the portion of surface which enters in displacement under the influence of the mining 
exploitation and is characterised by the following parameters: sinking, inclination, curvature, horizontal displacement and specific horizontal deformation.

\section{MATERIALS AND METHODS}

The horizontal displacement, the sinking and the deformation of the covering surface for the underground exploitation may be determined using a prognoses study using parameters determined through measurements in vertical and horizontal plan (Onica, 2001; Rancea 1990).

The quality and the precision of parameters depend especially on the multitude and diversity of the topographic measurements in the stations for the observance of the displacement and deformation of the surface under the influence of the exploited underground space. The requirements imposed to the results of the topographic measurements are linked to the precision of the measurements and other factors. The location of the observance station was selected so the coal-face in exploitation is the only factor to influence the field and the surface is sufficiently large (Onica, 2006; Ștefan, 2015).

Planting topographic markers is done inside and outside the field that is supposed to be influenced so all the obtained details reflect the displacement and the deformation of the field and the factors that influence in an unfavourable manner the constructions (Ortelecan and Pop, 2005; Palamariu and Popa, 2008).

The coordinates inventory of the determined points is comparatevely presented as follows.

The materials and the documents used in our research were obtained courtesy to Complexul
Energetic Hunedoara, the former Compania Naţională a Huilei S.A. of Petroşani, România.

The topographic measurements for our research were performed inside the urban area of Petrila, Lonea residential area, Deforului street, Hunedoara county, with the help of the total station, using the method of polygonation supported at two ends, from which were determined all the markers necessary for the study of subsidence.

\section{RESULTS}

The results obtained in the present study were carefully depicted under the form of diagrams, permitting a prognosis of the influence that the subsidence has upon the anthropic environment, leading to a vision in taking decisions for the durable development of the affected areas in the east of the mining basin of Petroşani.

The presented results are obtained after specific calculation of each parameter characteristic to the sinking bed.

Sinking $\left(S_{i}\right)$ - is defined as the vertical component of the displacement vectors for the points located at the surface, in the sinking bed.

$S_{i}=H_{i}-H_{i}^{*} S_{i}=H_{i}-H_{i} *$, in mm

- Where: $H^{*}{ }_{i}$ is the cote for point $i$ at the zero measurement; $\mathrm{Hi}$ - the cote of point $\mathrm{i}$ at a certain moment in time.

Inclination $(I)$ - represents the differential variant of the vertical displacement and is obtain through the report between the sinking difference between two consecutive markers from the sinking bed and the horizontal distances between these markers.

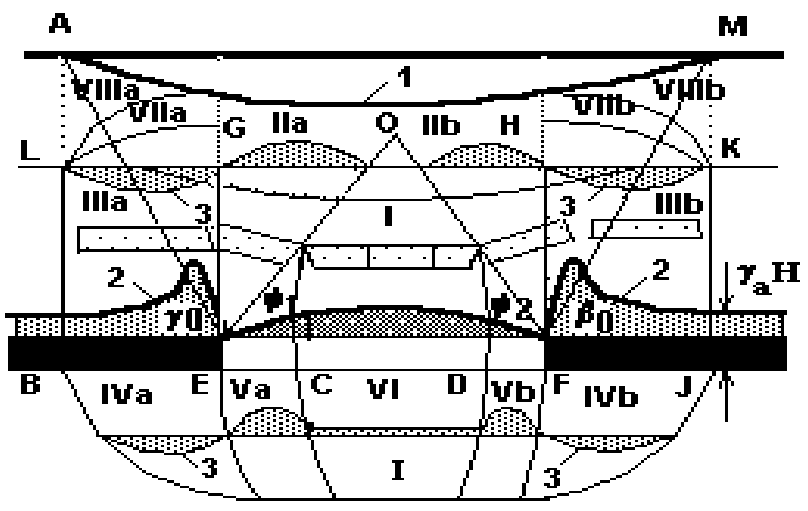

Fig. 2. General scheme of influence and displacement area [3].

1 - sinking bed; 2 - normal tension sketch; 3 - graphic of the rocks deformation after normal. 




Fig. 3. The general direction of the observance markers in the studied area

Tab. 1. The coordinate inventory upon the comparative situation of data obtained through topographic measurements in the time interval between September 2009 and April 2015

\begin{tabular}{ccccccc}
\hline \multicolumn{7}{c}{ COMPARATIVE SITUATION OF DATA OBTAINED THROUGH TOPOGRAPHIC MEASUREMENTS BETWEEN } \\
\multicolumn{7}{c}{ SEPTEMBER 2009 AND APRIL 2015, } \\
\multicolumn{7}{c}{ HUNEDOARA COUNTY, PETRILA, LONEA RESIDENTIAL AREA, DEFORULUI STREET } \\
\hline POINTS & \multicolumn{2}{c}{ MEASURED POINTS IN September 2009 } & \multicolumn{3}{c}{ MEASURED POINTS IN April 2015 } \\
\hline $\mathbf{F}$ & 439432.532 & 377126.175 & 708.288 & 439432.575 & 377126.161 & 708.274 \\
$\mathbf{E}$ & 439371.307 & 377145.659 & 708.325 & 439371.307 & 377145.659 & 708.336 \\
$\mathbf{1 0 0 0}$ & 439411.912 & 377106.664 & 704.940 & 439411.487 & 377110.383 & 705.113 \\
$\mathbf{1 0 0 1}$ & 439321.091 & 377161.419 & 706.959 & 439324.925 & 377164.387 & 707.069 \\
$\mathbf{1 0}$ & 439269.083 & 377190.456 & 708.683 & 439268.980 & 377190.420 & 708.664 \\
$\mathbf{2 0}$ & 439237.446 & 377209.552 & 708.832 & 439237.172 & 377209.555 & 708.695 \\
$\mathbf{3 0}$ & 439193.320 & 377235.277 & 708.807 & 439192.681 & 377235.509 & 708.209 \\
$\mathbf{4 0}$ & 439185.168 & 377246.252 & 707.966 & 439182.258 & 377251.788 & 707.178 \\
$\mathbf{8 0}$ & 439144.859 & 377214.412 & 714.707 & 439143.253 & 377216.009 & 712.835 \\
$\mathbf{2 3 3}$ & 438940.067 & 377367.312 & 714.986 & 438934.163 & 377369.182 & 716.167 \\
$\mathbf{2 3 4}$ & 438921.762 & 377377.744 & 720.891 & 438922.126 & 377376.637 & 720.500 \\
$\mathbf{2 3 5}$ & 438901.035 & 377389.732 & 724.960 & 438901.304 & 377388.553 & 724.600 \\
\hline
\end{tabular}




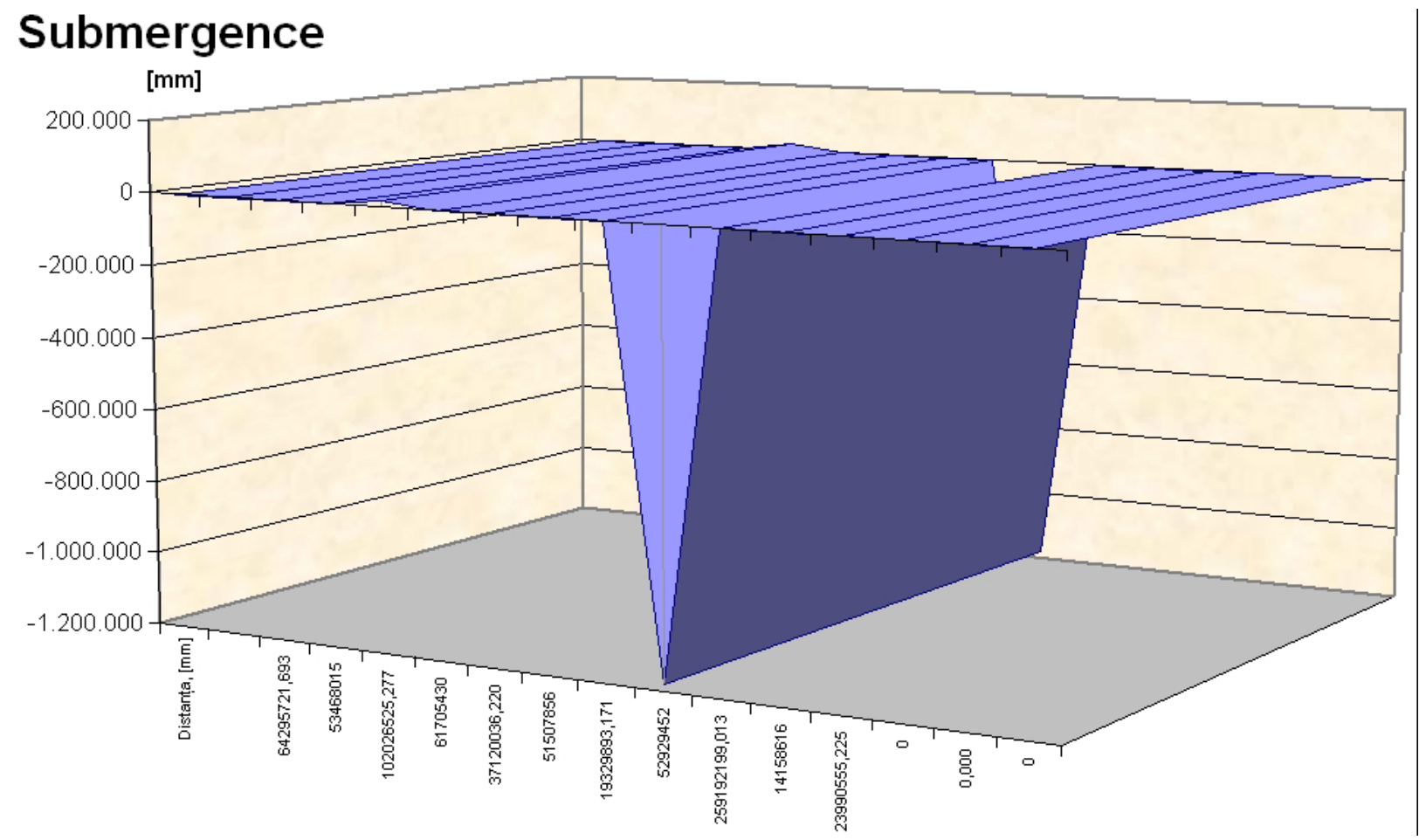

Fig. 4. The sinking resulted between September 2009 and April 2015

\section{Inclination}

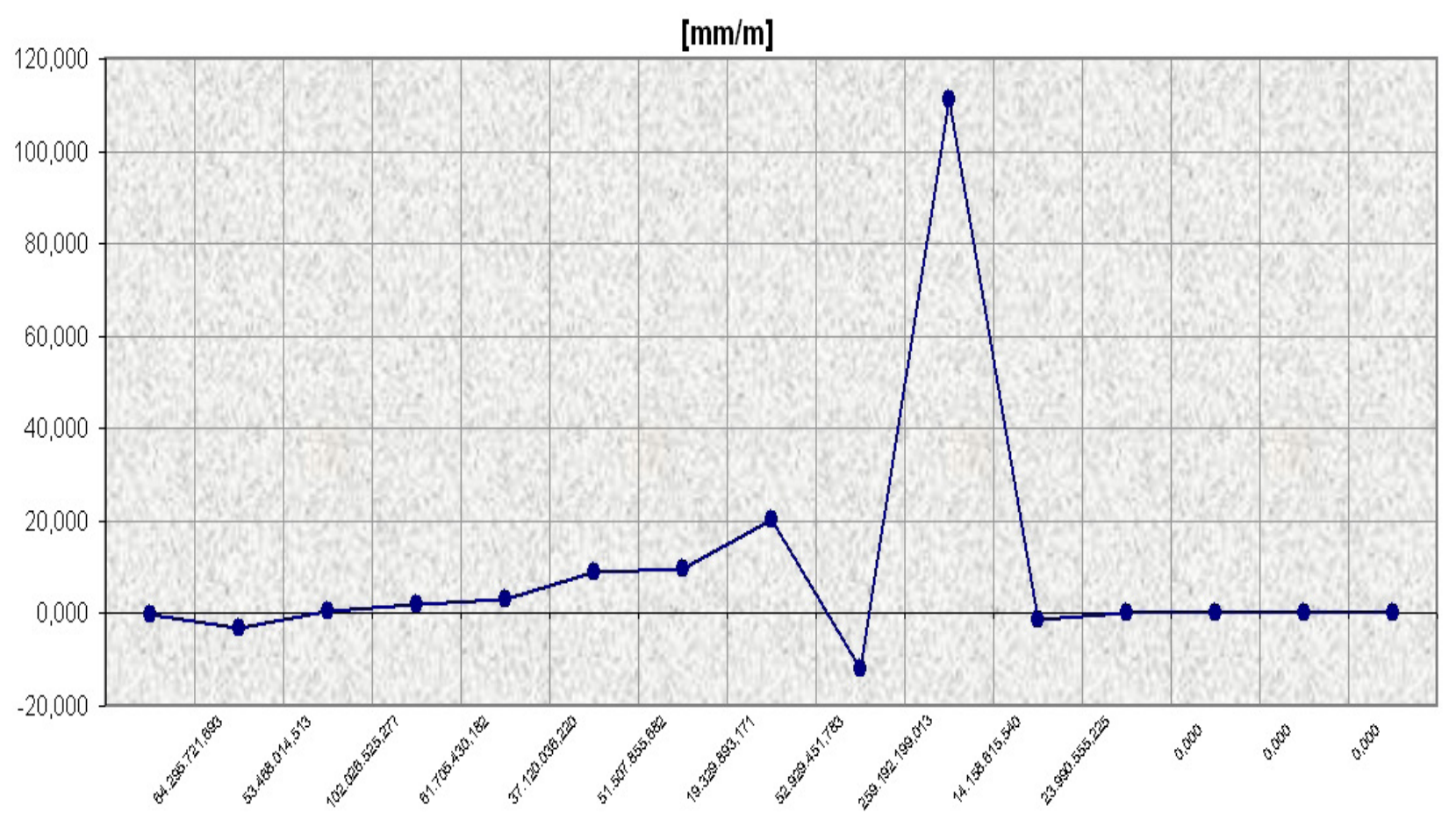

Fig.5. Inclination resulted for the time interval between September 2009 and April 2015 


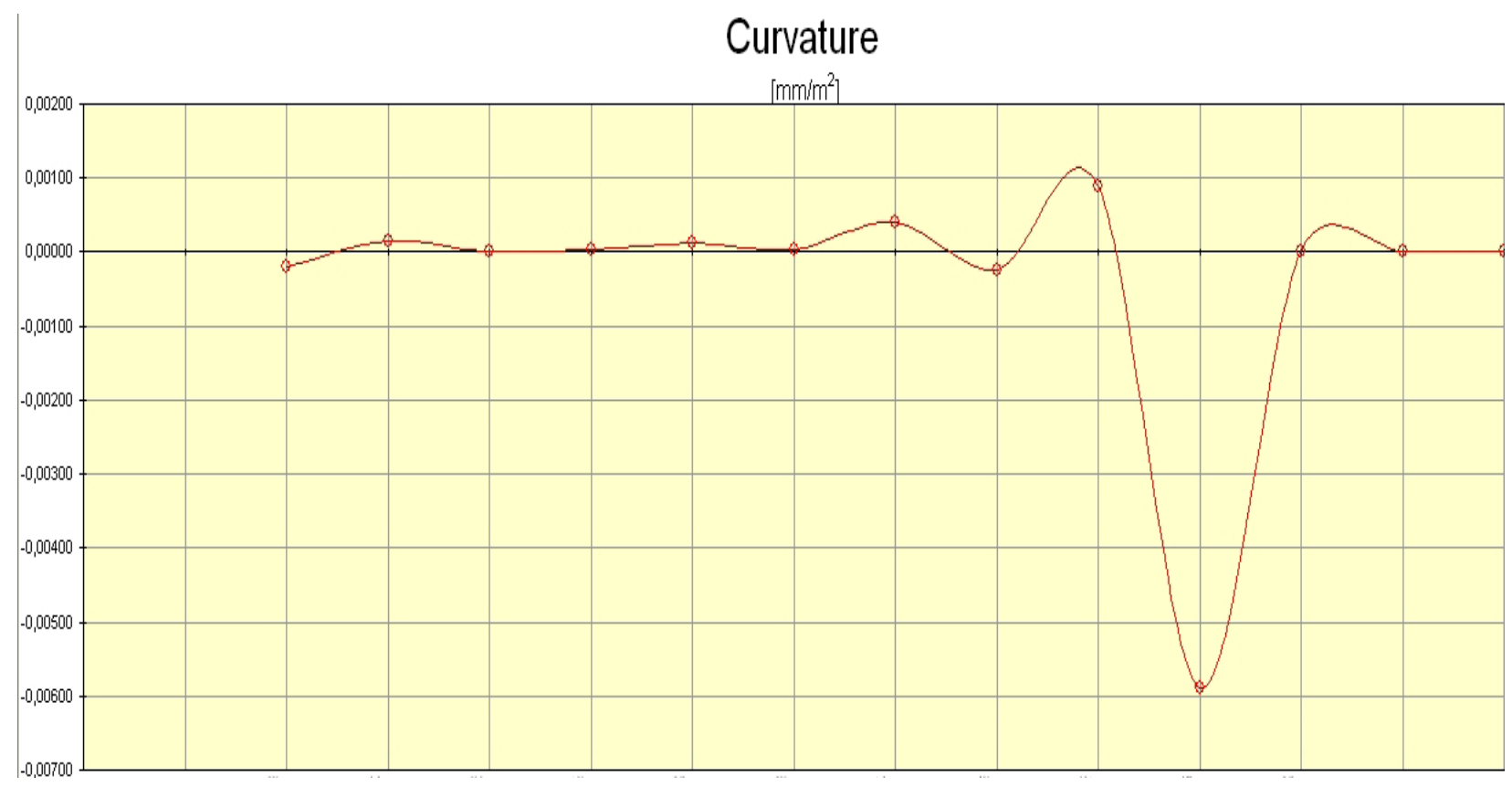

Fig. 6. The curvature of the sinking bed resulted for the time interval between September 2009 and April 2015

\section{Horızontal displacement}

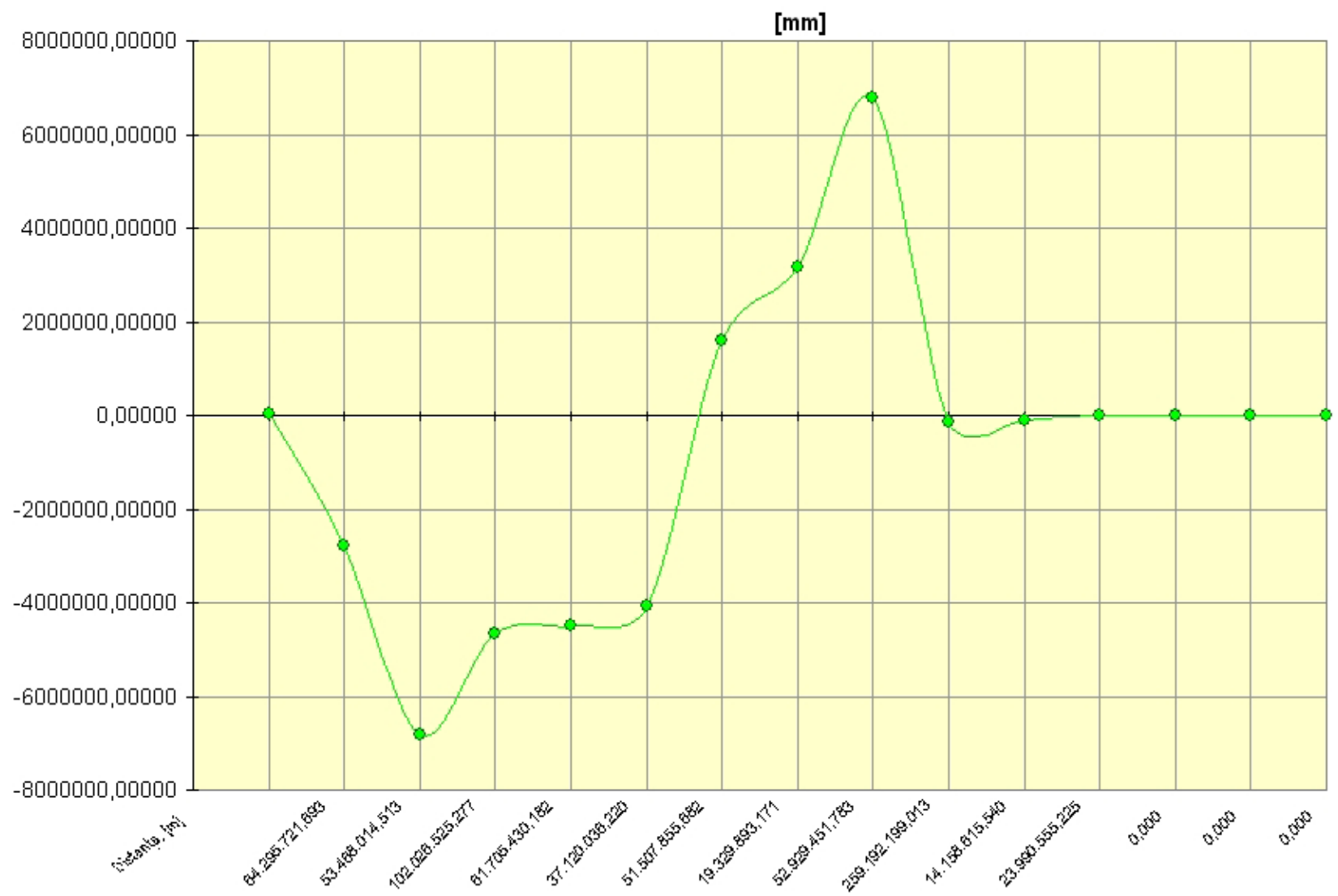

Fig. 7. The curvature of the sinking bed resulted for the time interval between September 2009 and April 2015 
$I_{i}=\frac{S_{i+1}-S_{i}}{D_{0_{i, i+1}}}$, in $\mathrm{mm} / \mathrm{m}$

where: $S_{i}$ is the sinking of the current marker $i$; $S_{i, i+1}$ - the sinking of the consecutive marker $i+1$;

$D_{0_{i, i t 1}}$ - the horizontal distance between the two markers.

The curvature of the sinking bed $(K)$ - is defined as the inclination difference between two neighbour intervals and half of the addition of these intervals. The curvature is equal to the derivate of the inclination or is equal to the second derivation of sinking reported to the horizontal variable.

$K=\frac{I_{i+1}-I_{i}}{D_{0_{i, i+2}}}$, in $\mathrm{mm} / \mathrm{m}^{2}$

where: $I_{i}$ represents the inclination of the field between the markers $i$ and $i+1 ; I_{i+1 ;}$ inclination of the field between $i+1$ şi $i+2 ; D_{0_{i, i+2}}$ - the horizontal distance measured between the points $i \rightarrow i+1$ şi $i+1 \rightarrow i+2$.

The horizontal displacement $\left(\Delta D_{i}\right)$ represents the horizontal component of the displacement vectors for the points located in the syncline of the displacement. Two neighbour points located in the displacement area of the surface describe a similar direction, but it is observable that the distance which separates them

to their origin ( $\left.D_{0_{i, i+1}}^{*}\right)$ is not the same at the end of the displacement $\left(D_{0_{i, i+1}}^{c}\right)$.

$$
\Delta D_{i}=D_{0_{i, i+1}}^{c}-D_{0_{i, i+1}}^{*}, \text { in mm }
$$

where: $D_{0_{i j i 1}}^{c}$ is the horizontal distance between two consecutive points at the current measurement; $D_{0_{i j i 1}}^{*}$ - the horizontal distance between two consecutive points for the zero measurement.

Specific horizontal deformation, $[\mathrm{mm} / \mathrm{m}]$

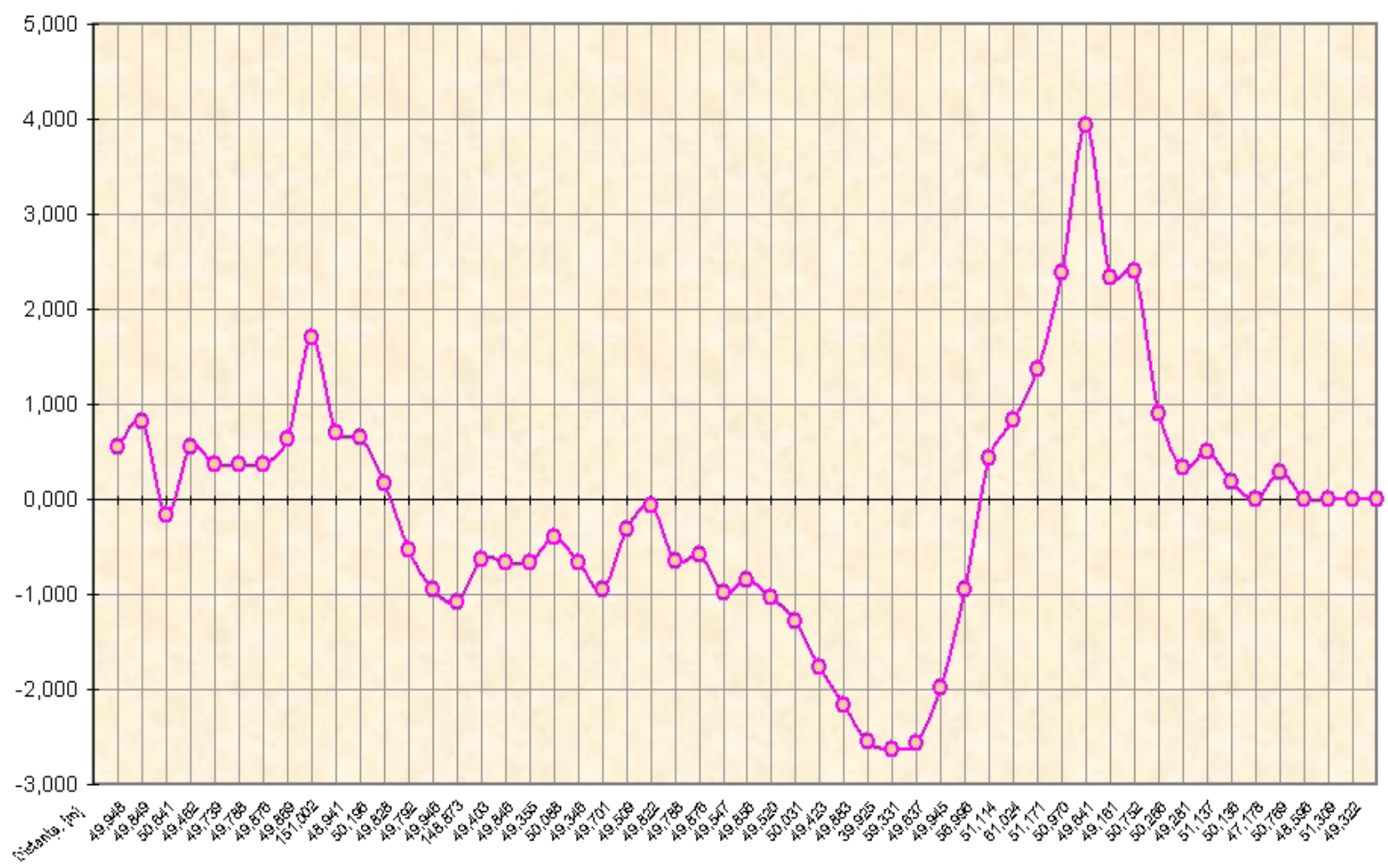

Fig. 8. The curvature of the sinking bed resulted for the time interval between September 2009 and April 2015 
The specific horizontal deformation ( $\varepsilon_{i}$ ) - expresses the length variation for the interval between two consecutive points reported to the length in the base measurement.

$\varepsilon_{i}=\frac{\Delta D_{i}}{D_{0_{i, i+1}^{*}}^{*}}$, in $\mathrm{mm} / \mathrm{m}$

where: $\Delta D_{i}$ is the horizontal displacement of marker $i ; D_{0_{i, i+1}}^{*}$ - the horizontal distance between the marker i and marker $i+1$ for the initial measurement.

\section{CONCLUSION}

The subsidence phenomenon continues to be of large interest due to its implications in the urban planning, environmental protection and constructions at the surface. The subsidence phenomenon is known since the beginning of the last century. Identifying the strain and displacement of the surface under the influence of the underground mining is made only after geodesic and topographic measurements. The topographic supervising measurements for the behaviour in time of the surfaces are reported to fix markers placed outside the deformation area. The research show that, as a result of the observances in the affected areas, short, medium and long time prognoses may be obtained.

\section{REFERENCES}

1. Akimov DG (1970). Sdvijenie gornîh parod pri padzemnoi razrabotke ugolnîh slontevin Mestorojdenie, Ugletehizdat, Moscou, U.R.S.S.

2. Beldea M (2015). Calculul adâncimii de siguranţă pentru exploatarea stratului 5, în blocurile II-III ale perimetrului de exploatare Lonea, Petroşani, Romania.

3. Betounay MC (2002). Underground Mining and Its Surface Effect. Interstate Tehnical Group on Abandoned
Undergraound Mines, Fourth Biennial Abandoned Underground Mine Workshop, Davenport, Iowa.

4. Brauner G (1998). Subsidence due to Underground Mining. 1.Theory and practices in predicting surface deformaiton, Bureau of Mines Information Circular, U.S.A.

5. Chrzanowski A, Chrzanowski AS, Forrester DJ (1998). 100 Years of Ground Subsidence Studies, Proceedings of the 100 CIM Annual General Meeting, Montreal, Canada.

6. Knothe S (1957). Observations of Surface Movements Under Influence of Mining and Their Theoretical Interpretation, Proceedings European Congress on Ground Movement, University of Leeds, Leeds, Apr., pp. 210-218, U.K.

7. Marian DP (2012). Urmărirea topografică și analiza deformării suprafeței terenului afectat de exploatarea subterană, Universitas Publishing House, Petroșani, Romania.

8. Neamțu M, Onose D, Neuner J (1988). Măsurarea topografică a deplasărilor și deformațiilor construcțiilor, Bucharest Construction Institute, Romania.

9. Onica I (2001). Impactul exploatării zăcămintelor de s.u.m. asupra mediului, Universitas Publishing House, Petroșani, Romania.

10. Onica I (2006). Degradarea terenului de la suprafață sub influența exloatării subterane. AGIR Bulletin, no.3.

11. Ortelecan M (1997). Studiul deplasării suprafeței sub influenţa exploatării subterane a zăcămintelor din Valea Jiului, PhD Thesis, University of Petroşani, Petroşani, România.

12. Ortelecan M, Pop N (2005). Metode topografice de urmărire a comportării construcțtiilor şi terenurilor înconjuratoare, AcademicPres Publishing House, ClujNapoca, Romania.

13. Palamariu M, Popa A (2008). Urmărirea comportării terenurilor şi construcţiilor, Seria Didactică, Universitatea „1 Decembrie 1918” Alba Iulia, Alba Iulia, Romania.

14. Rancea G (1990). Dimensionarea pilierilor de protecţie pentru obiective de suprafața în condiţiile bazinului carbonifer Valea Jiului, PhD Thesis, University of Petroşani, Petroşani, România.

15. Ștefan N (2015). Studiul deformarii terenurilor aflate sub influenta exploatarii subterane a stratelor de carbune din bazinul minier Valea Jiului, PhD Thesis, University of Petroşani, Petroşani, România.

16. Youngh LE, Stoek HH (1916). Subsidence resulting from mining, University of Illions, U.S.A. 